\title{
Overexpression of chromatin assembly factor-1/p60 predicts biological behaviour of laryngeal carcinomas
}

\author{
L'espressività della proteina CAF-1 p60 come fattore prognostico nei carcinomi laringei

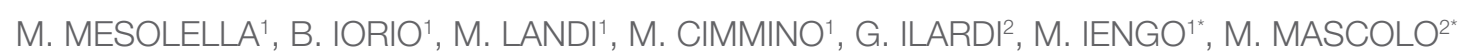 \\ ${ }^{1}$ Department of Neurosciences, ENT Section, University of Naples "Federico II", Naples, A.O.U. Federico II, Naples, \\ Italy; ${ }^{2}$ Department of Advanced Biomedical Sciences, Pathology Section, University of Naples "Federico II", Naples, \\ Italy. "These authors contributed equally to this work.
}

\section{SUMMARY}

This study analysed the immunohistochemical expression of the CAF-1/p60 protein in laryngeal cancers. CAF-1/p60 assumes an independent discriminative and prognostic value in laryngeal neoplasms; the presence of this protein in carcinoma in situ compared with laryngeal precancerous and larynx infiltrating tumours. We assessed the immunohistochemical expression of CAF-1/p60 in 30 cases of moderate and/or severe dysplasia, 30 cases of carcinoma in situ and 30 cases of laryngeal squamous cell carcinoma (LSCCs). CAF-1/p60 expression increased significantly according to the high index of neoplastic cellular replication; therefore, CAF-1/p60 was overexpressed in neoplastic cells and its moderate-severe expression is correlated with poorer prognosis compared to less expression. In conclusion, overexpression of the CAF-1/p60 protein is related to a risk of higher morbidity and mortality and is a reliable independent prognostic index of laryngeal carcinoma. CAF1-p60 protein overexpression can be used in cancer management as an indicator of malignant evolution, especially in carcinoma in situ.

KEY WORDS: CAF-1/p60 • Prognostic factor • Laryngeal cancer • Carcinoma in situ • Dysplasia • Tumoural marker

\section{RIASSUNTO}

CAF-1 è una proteina istonica trimerica implicata sia nella replicazione che nella riparazione del DNA, con il compito essenziale di stabilizzare la cromatina durante la replicazione; presenta un' azione di assemblaggio del tutto tipica, poiché unisce solo DNA che è andato incontro a replicazione. Di recente la proteina CAF-1p60 è stata proposta come marker della proliferazione cellulare nei tumori solidi, in particolare nel distretto testa- collo in virtù della sua iper-espressione nelle cellule in stato di proliferazione rispetto a quelle quiescenti in cui è down- regolata. Questa relazione con l'attività mitotica ha inoltre permesso di considerarla come possibile indice prognostico di aggressività neoplastica. In precedenti lavori, effettuati presso il nostro dipartimento, abbiamo documentato che tale proteina risulta essere iper-espressa nei tumori del cavo orale, delle ghiandole salivari e della tiroide. In questo studio abbiamo analizzato e confrontato l'espressività immunoistochimica della proteina CAF-1/p60 nelle neoformazioni laringee precancerose, nei carcinomi in situ e nei tumori maligni, in particolare: in 30 casi di displasia moderata elo severa, 30 casi di carcinoma in situ e 30 casi di SCCs. CAF-1/p60 è iperespressa nelle cellule neoplastiche; l'espressione di CAF-1/p60 aumenta significativamente in correlazione all'alto indice di replicazione cellulare; inoltre la sua iperespressione moderata-severa è correlata con una prognosi peggiore comparata con la lieve e l'iperespressione della proteina $C A F-1 / p 60$ è correlata con un più alto rischio di morbilità e mortalità rappresentando un reale indice prognostico delle neoplasie laringee. CAF-1/p60 assume, pertanto, un valore prognostico indipendente nelle neoplasie laringe. Riteniamo, dunque, che l'iperespressione della proteina CAF-1/p60 che possa essere usata come indicatore di aggressività nell'evoluzione maligna specie dei carcinomi in situ ed impiegata nel follow-up per identificare le forme a più alto rischio prognostico che necessitano quindi controlli più ravvicinati nel tempo.

PAROLE CHIAVE: Proteina CAF-1/p60 • Fattori prognostici $\bullet$ Carcinoma della laringe $\bullet$ Carcinoma in situ $\bullet$ Displasie laringee $\bullet$ Lesioni precancerose $\bullet$ Marker tumorali

Acta Otorhinolaryngol Ital 2017;37:17-24

\section{Introduction}

Laryngeal carcinoma (LC) represents one of the most common head and neck cancers and accounts for approximately $5.1 \%$ of all tumours in more developed areas and $3.5 \%$ in less developed areas, worldwide ${ }^{12}$. The estimated incidence of laryngeal cancer in 2012 is about $1.1 \%$ of all cancers, with nearly 157,000 new cases in $2012^{3}$.
Currently, contrary to other anatomic districts (breast, colon etc.), for LC there are no specific and sensitive markers that can be used for early diagnosis and follow-up, beyond the available prognostic parameters ${ }^{45}$. Cell proliferative activity has been extensively investigated in head and neck tumours, including LC, as useful diagnostic and prognostic marker; however, its specific role has yet to be definitively established. 
Over the last decade, it has been demonstrated that in head and neck carcinogenesis, the transition from normal epithelium to pre-malignancy, and finally to carcinoma is related to the accumulation of genetic and epigenetic alterations, is a multistep process. The most important epigenetic alterations include DNA methylation, histone modifications and RNA-mediated silencing. Chromatin assembly and remodelling is strictly regulated by histone chaperones. Chromatin assembly factor-1 (CAF-1), a histone chaperone, is an heterotrimeric protein complex formed of three subunits (p48, p60 and p150) ${ }^{67}$. CAF-1/p60 has recently been proposed as a new sensible proliferation marker in malignant tumours ${ }^{89}$. In particular, CAF-1/p60 is down regulated in quiescent cells, whereas it is overexpressed in hyper-proliferating and neoplastic cells ${ }^{10}$.

CAF-1 plays a crucial role in the assembly and repositioning of nucleosomes on newly synthesised DNA, regulating replication processes and DNA repair ${ }^{10-14}$. The p150 subunit appears to be more active in repair processes, while CAF-1/p60 is more specifically connected to controlling cell replication. The p48 subunit intervenes on acetylation/deacetylation of histones by specific protein complexes ${ }^{15-17}$.

In detail, CAF-1 mediates the epigenetic regulation of the state of chromatin aggregation, contributing to maintenance of chromosome structure before and after the formation of hairpin replication and appears to be involved in the transient destabilisation of nucleosomes required for the progression of hairpin replication.

CAF-1 has a typical assembly action, since it assembles only replication DNA. This is due to the fact that its activity necessarily requires interaction with the proliferating cell nuclear antigen (PCNA), which, as is known, specifically marks the newly synthesised DNA and is involved in the processes of replication, repair, recombination, repair of single strand breaks (SSB) and sister chromatid cohesion ${ }^{18-22}$. Ultimately, CAF-1 plays a critical role in maintaining the stability of chromatin during DNA replication and deregulation of this control mechanism can cause an uncontrolled proliferation, resulting in cancer ${ }^{10} 1718$.

In this study, we investigated the expression of CAF-1/p60 in laryngeal carcinomas to determine whether this protein could represent a reliable biological marker in evaluating tumour behaviour. Finally, we explored the possibility that this protein may represent a promising novel chance to plan for more concise follow-up, type of re-operation, or alternative treatment.

\section{Materials and methods}

\section{Patients}

The study population was selected from patients treated at the Otolaryngology, Head and Neck Surgery Department of the Federico II University, Naples, Italy, from 1 January 2000 to 31 December 2014. Inclusion criteria were:
- patients with laryngeal dysplastic precancerous lesions and laryngeal carcinoma in situ, treated surgically by excision biopsy or cordectomy (Type I, II, III, IV and $\mathrm{V}$ according to the classification of the European Laryngological Society, 2000) with the aid of $\mathrm{CO}_{2}$ laser in accordance with the World Health Organization classification system (WHO) $2005^{23}$;

- patients with early laryngeal infiltrating neoplasm (squamous cell carcinoma) treated surgically with supraglottic, subtotal or total laryngectomy;

- post-operative patients during oncological follow-up in a specialised laboratory at our clinic, with ENT specialist examinations by direct fibre optic laryngoscopy through video recording and in accordance with the timetable guidelines for each dysplastic lesion or tumour stage;

- the same selected series of patients had been evaluated for CAF-1/ p60 by immunohistochemistry (Pathology section of the Department of Advanced Biomedical Sciences, Federico II University of Naples).

According to these inclusion criteria, the study population consists of 90 cases of laryngeal lesions. We divided this population into three subgroups:

a. moderate and/ or severe dysplasia: 30 cases;

b. carcinoma in situ: 30 cases;

c. infiltrating cancer: 30 cases.

The population of subgroup B is composed of all consecutive cases with definitive diagnosis of carcinoma in situ (diagnosis relatively less frequent) from 1 January 2000 to 31 December 2014. To highlight the features of CAF-1/p60 expression in carcinoma in situ, this subgroup was compared to the same number of consecutive cases of dysplasia (subgroup A) and infiltrating carcinomas (subgroup C) of the larynx, from a larger series, and that respected the following inclusion criteria:

- smoking more than 20 cigarettes per day for over 20 years and who continue to smoke upon diagnosis;

- negative anamnesis for alcohol abuse;

- negative anamnesis for exposure to environmental risk factors in the work place;

- absence of any clinical and anamnestic indirect signs of gastroesophageal reflux.

Formalin-fixed paraffin-embedded blocks were selected from the archive of the Department of Advanced Biomedical Sciences, Pathology Section, Federico II University II of Naples.

For each case, paraffin blocks containing tumour areas representative of the lesion were stained for CAF-1/p60 immunohistochemical expression by comparing $\mathrm{A}, \mathrm{B}$ and C subgroups.

The study was performed in accordance with the guidelines of the Institutional Ethics Committee, Italian law, and the Declaration of Helsinki, as required for studies based on retrospective analyses on routine archival formalin-fixed, paraffin-embedded tissue. All patients provided written informed consent regarding use of data. 


\section{Immunohistochemistry}

For each case, 4- $\mu$ m-thick serial sections were cut and mounted on poly-L-lysine coated glass slides. Deparaffinised sections of all cases were boiled three times for $3 \mathrm{~min}$ in $1 \mathrm{mM}$ sodium citrate buffer ( $\mathrm{pH}$ 6.0) for antigen retrieval. In order to prevent the non-specific binding of the antibody, sections were pre-incubated with non-immune mouse serum (1:20, Dakopatts, Hamburg, Germany) diluted in PBS/BSA, $1 \%$, for $25 \mathrm{~min}$, at room temperature. After quenching of endogenous peroxidase activity was blocked by the incubation in $3 \%$ hydrogen peroxide for $30 \mathrm{~min}$., followed by two rinses with Tris$\mathrm{HCl}$ buffer, sections were incubated overnight at $4^{\circ} \mathrm{C}$ with the anti-CAF-1/p60 antibody (SS53 - ab8133, Abcam, Cambridge, MA, USA), diluted 1:300.

The standard streptavidin-biotin-peroxidase complex technique was performed, using sequential 30-min incubation with biotin-labelled secondary antibody and with peroxidase-labelled streptavidin for $30 \mathrm{~min}$ (DAKO LSAB kit HRP, Carpinteria, CA). For development of peroxidase activity, 3,3'-diaminobenzidine (DAB, Vector Laboratories, Burlingame, USA) was used as a substrate chromogen solution. Haematoxylin was used for nuclear counterstaining; sections were then mounted and cover-slipped with a synthetic mounting medium (Entellan, Merck, Germany). For each staining, sections from breast cancer were used as positive controls and for negative controls the sections were incubated with pre-immune serum instead of primary antibody. Only cells with definite brown nuclear staining were judged positive.

The expression of CAF-1/p60 was then rated semi-quantitatively according to an arbitrary scale, as follows: 0 $(<10 \%$ of positive cells $) ;+(10 \%-<20 \%) ;++(20 \%$ $-<30 \%) ;+++(>30 \% \text { of positive cells })^{24}$.

\section{Statistical analysis}

Statistical analysis was performed using Med-Calc (version 9.3.7.0), comparing the expressiveness of CAF-1/ p60 between the A-B-C groups using the Wilcoxon/ Mann-Whitney test for independent and non-parametric variables. According to literature, we assigned numeric values between 0 and 3 to different degrees of CAF-1/ p60 expression (negative: 0; mild expression +: 1 ; moderate expressivity $++: 2$; severe expressivity $+++: 3$ ). We applied the Kaplan-Meier method, normalising the different categories by the log-rank Mantel-Haenszel test to compare overall and specific disease survival. A Cox proportional hazard model was used to assess the simultaneous contribution of multiple factors to the risk mortality. We performed multivariate Cox regression analysis for significant variables found in univariate analyses (overexpression, staging, grading, treatment strategy, progress and distant metastasis) to underline HR of patients with moderate-severe and severe $\mathrm{CAF}-1 / \mathrm{p} 60$ expression. In each test, a $\mathrm{p}$ value $<0.05$ was considered statistically significant.

\section{Results}

The study population consists of 90 patients, 85 men and 5 women. The median age was 71 years (range, 37-86 years). Follow-up was performed in all patients (median: 33 months; range: 9-104 months).

\section{Dysplasia}

Patients with moderate and/or severe dysplasia showed a mild (+) expression of CAF-1/p60 in all cases evaluated (100\%) (Fig. 1).

All patients underwent regular oncological follow-up at our clinic. During follow-up, direct laryngoscopy in 2 patients highlighted an area of suspected recurrence. These patients underwent a surgical procedure for enlargement of the previous excision (cordectomy type II vs. cordectomy type I). The histological examination relating to this procedure indicated mild dysplasia. Survival with organ and function preservation in such cases is $100 \%$ (Table I).

\section{Carcinoma in situ}

All malignant tumours showed a CAF-1/p60 overexpression (19 cases + , one case,++ 4 cases $++/+++, 6$ cases +++ ) (Fig. 1). During follow-up, 2 patients $(6.6 \%)$ died. The first of laryngeal carcinoma in situ (mild CAF1/p60 expression) showed a metachronous oesophageal cancer and died of disease. In the second case, characterised by strong expression (+++) of CAF-1/p60, the death was due to recurrence and progression of disease. Twenty-eight patients $(93.4 \%)$ continued oncological follow-up;

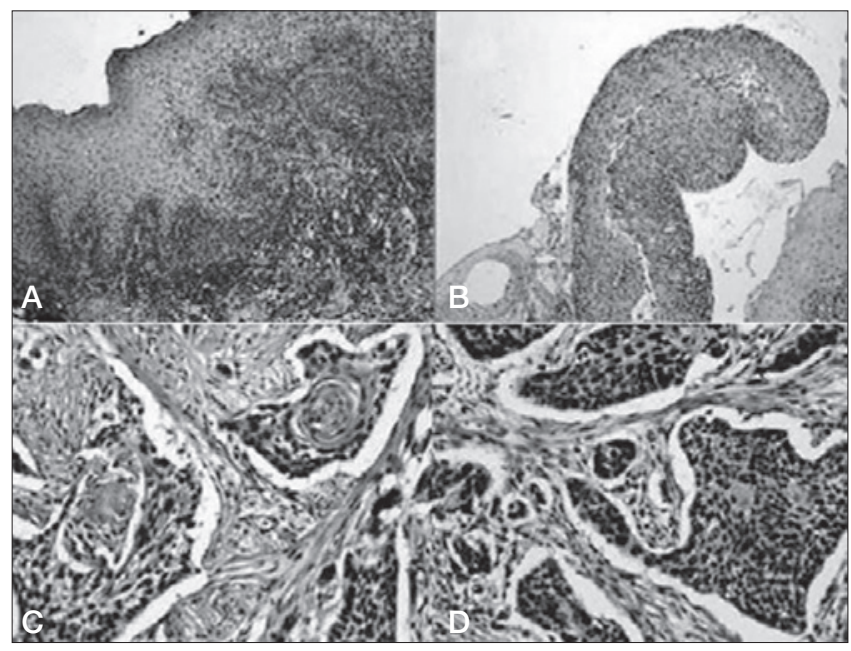

Fig. 1. A) Laryngeal mucosa with moderat-severe dysplasia and with mild $(+)$ expression of CAF-1/p60; B) Laryngeal mucosa with cancer in situ and with severe $(+++)$ expression of CAF-1/ p60; C- D) High expression (+++) of CAF-1/ p60 in moderately differentiated cancer (G2) and in undifferentiated cancer (G3). 
Table I. Dysplasia; correlation of CAF-1/p60 expression with surgical treatment and follow-up.

\begin{tabular}{lcccccc} 
Case & $\begin{array}{c}\text { Histological } \\
\text { diagnosis }\end{array}$ & CAF1/P60 & First treatment & F-UP & $\begin{array}{c}\text { Second } \\
\text { treatment }\end{array}$ & F-UP \\
18 & Dysplasia & + & Cordectomy type I & Normal & - & - \\
10 & Dysplasia & + & Cordectomy type II & Normal & - & - \\
2 & Dysplasia & + & Cordectomy type I & Relapse & Cordectomy type II Normal \\
\hline
\end{tabular}

in 19 patients, the follow-up was regular without the need for further treatment (CAF-1/p60 score was + in 17 of 19 cases and ++ and ++/+++ in 2 cases). Of the remaining 9 patients whose direct laryngoscopy revealed an area of suspected relapse, 2 (CAF-1/p60 score +++) underwent excisional biopsy, with histological examination revealing varying degrees of dysplasia, while the remaining 5 (CAF-1/p60 score, respectively, one case + , one case $++/+++, 3$ cases +++ ) underwent a second surgical procedure to enlarge the previous excision because of the location of the lesion (anterior) and positive involvement of the resection margins. Histology revealed a recurrent carcinoma in situ. Only 2 cases (CAF-1/p60 score ++/+++) underwent laryngectomy (total and supraglottic) for laryngeal disease progression. Specific survival with organ and function preservation in such cases was $96.6 \%$ considering that one patient did not die of laryngeal disease (Table II).

\section{Infiltrating carcinoma}

Patients with invasive squamous cell carcinoma were treated surgically by laryngectomy. In 18 patients (60\%) the tumour was glottic, in 9 patients (30\%) supraglottic and 3 patients (10\%) had subglottic extension. The grading of the neoplasm was moderately differentiated (G2) in 10 patients (33.3\%), from moderately to poorly differentiated (G2-G3) in 9 patients $(30 \%)$ and undifferentiated (G3) in 11 patients (36.6\%).

Among the cancers with an intermediate degree of differentiation (G2), 6 of 10 cases showed a moderate expression of CAF-1/p60 (++) and continued with regular follow-up; one patient died of disease $(++)$, one case $(++/+++)$ died of disease. The remaining 2 cases who had metastases at follow-up and died of the disease, showed a score of +++. All moderately to poorly differentiated (G2/ G3) squamous cell carcinomas showed CAF-1/p60 moderate $(++)$ staining in 3 cases, moderate-high $(++/+++)$ in

Table II. Cancer in situ; correlation of CAF-1/p60 expression with surgical treatment and follow-up.

\begin{tabular}{|c|c|c|c|c|c|c|}
\hline Cases & $\begin{array}{l}\text { Histological } \\
\text { diagnosis }\end{array}$ & $\begin{array}{l}\text { CAF-1/ } \\
\text { P60 }\end{array}$ & First treatment & Follow-up & Second treatment & Follow-up \\
\hline 3 & Ca in situ & + & Cordectomy type I & Normal & - & - \\
\hline 5 & Ca in situ & + & Cordectomy type II & Normal & - & - \\
\hline 4 & Ca in situ & + & Cordectomy type III & Normal & - & - \\
\hline 4 & Ca in situ & + & Cordectomy Type IV & Normal & - & - \\
\hline 1 & Ca in situ & + & Cordectomy type Va & Normal & - & - \\
\hline 1 & Ca in situ & + & Cordectomy type II & Relapse ca in situ & Cordectomy type IV & Normal \\
\hline 1 & Ca in situ & + & Cordectomy type IV & $\begin{array}{c}\text { tfor esophagus } \\
\text { metachronous cancer }\end{array}$ & - & - \\
\hline 1 & Ca in situ & ++ & Cordectomy type III & Normal & - & - \\
\hline 1 & Ca in situ & $++/+++$ & Cordectomy type III & Normal & - & - \\
\hline 1 & Ca in situ & $++/+++$ & Cordectomy type III & Progression of disease & $\mathrm{TL}$ & Normal \\
\hline 1 & Ca in situ & $++/+++$ & Cordectomy type IV & Relapse ca in situ & Cordectomy type Va & Normal \\
\hline 1 & Ca in situ & $++/+++$ & Cordectomy type Vd & Progression of disease & SGPL & Normal \\
\hline 1 & Ca in situ & +++ & Cordectomy type III & Suspect of relapse & $\begin{array}{l}\text { Excisional biopsy } \\
\text { (grave dysplasia) }\end{array}$ & $\begin{array}{c}4 \text { biopsy } \\
\text { (light dysplasia) }\end{array}$ \\
\hline 1 & Ca in situ & +++ & Cordectomy type IV & Relapse ca in situ & Cordectomy type Va & Normal \\
\hline 2 & Ca in situ & +++ & Cordectomy type Va & Relapse ca in situ & Cordectomy type Vd & Normal \\
\hline 1 & Ca in situ & +++ & Cordectomy type Va & $\begin{array}{l}\text { Suspect of } \\
\text { relapse }\end{array}$ & $\begin{array}{l}\text { Excisional biopsy (light } \\
\text { dysplasia) }\end{array}$ & Normal \\
\hline 1 & Ca in situ & +++ & Cordectomy type Vd & $\begin{array}{c}t \text { for progression of } \\
\text { disease }\end{array}$ & - & - \\
\hline
\end{tabular}


3 cases and high (+++) in the remaining 3 cases. Three cases developed metastases during follow-up (2+++ and $1++/+++)$. In poorly-differentiated squamous cell carcinomas (G3), the CAF-1/p60 was expressed at moderate levels (score ++$)$ in 5 cases, and high levels $(+++)$ in 6 cases; 3 patients $(2+++$ and $1++)$ presented metastases during follow-up (Figure 1).

Post-operative patients received oncology counselling and radiotherapy and 22 patients $(73.3 \%)$ received adjuvant chemotherapy and/or radiotherapy. During follow-up at our dedicated clinic, 10 patients $(33.3 \%)$ died of disease (CAF-1/p60 score ++ in 3 cases, ++/+++ in one case and +++ in 6 cases), 8 of whom presented distant metastasis (CAF-1/p60 score +++ in 6 cases, , ++/+++ in one case and ++ in one case). Five patients died of other diseases (CAF-1/p60 score ++ in 2 cases, $++/+++$ in 2 cases and +++ in one case) and the remaining 15 patients had follow-up free of disease. Survival in such cases was $66.6 \%$ considering that five patients did not die of laryngeal disease (Table III).

\section{Statistical analysis}

Statistical analysis for non-parametric variables showed a $\mathrm{p}=0.0015$ in comparing group A, dysplasia, with group $\mathrm{B}$, carcinomas in situ of the larynx (statistically significant). Comparison between group A, dysplasia, and group $\mathrm{C}$, infiltrating tumours, showed a $\mathrm{p}<0.0001$ (highly statistically significant). Comparison between group B, carcinoma in situ, and group $\mathrm{C}$, infiltrating tumours, revealed a $p=0.0008$ (statistically significant). Analysis of the survival rate in the study population showed a statistically significant $p$ value $(\mathrm{p}=0.0178)$, which became more significant in specific disease survival $(p=0.0070)$ with a cumulative survival probability of $100 \%$ within 9 months of diagnosis in patients with severe expressiveness of the CAF-1/p60 protein (+++); $100 \%$ within 16 months of diagnosis in patients with moderate-severe expressiveness of CAF-1/p60 (++/+++); $100 \%$ within 32 months of diagnosis in patients with moderate expressiveness (++) of the p60 protein. No patient with mild expressiveness died of laryngeal cancer. We deduce that the probability of an adverse event (metastasis-death) is greater in cases with severe expression (score +++) of the p60 protein (Fig. 2). A Cox proportional hazards model was used to verify whether the overexpression of the p60 protein and other variables are independent prognostic factors for LSCC patients. Univariate analysis showed that overexpression, staging, grading, treatment strategy, progress and distant metastasis were associated with survival in patients with LSCC. Multivariate analysis of the same variables showed that those variables were independent prognostic factors for patients with LSCC, and overexpression of the p60 protein was significantly associated with poor prognosis.
Table III. Infiltrating cancer; correlation of CAF-1/p60 expression with surgical treatment and follow-up.

\begin{tabular}{|c|c|c|c|c|c|}
\hline Case & $\begin{array}{l}\text { Histological } \\
\text { diagnosis }\end{array}$ & $\begin{array}{l}\text { Grading/ } \\
\text { staging }\end{array}$ & $\begin{array}{l}\text { CAF-1 } \\
\text { /P60 }\end{array}$ & $\begin{array}{l}\text { Surgical } \\
\text { treatment }\end{array}$ & F-UP \\
\hline 1 & LSCC & II/ G2 & +++ & SCPL & $t-\mathrm{M}_{+}$ \\
\hline 2 & LSCC & II/ G2 & ++ & $\mathrm{TL}$ & Normal \\
\hline 3 & LSCC & III/ G2-G3 & ++ & SCPL & Normal \\
\hline 4 & LSCC & III/ G2- G3 & ++ & SGPL & $t$ \\
\hline 5 & LSCC & IVa/ G2 & +++ & SCPL & $t-\mathrm{M}_{+}$ \\
\hline 6 & LSCC & IVa/ G2 & ++ & SCPL & Normal \\
\hline 7 & LSCC & IVa/ G2- G3 & ++ & SCPL & Normal \\
\hline 8 & LSCC & IVa/ G3 & ++ & SGPL & $\begin{array}{l}\text { t for other } \\
\text { disease }\end{array}$ \\
\hline 9 & LSCC & IVa/ G3 & ++ & SGPL & Normal \\
\hline 10 & LSCC & IVa/ G3 & ++ & SCPL & $t-M_{+}$ \\
\hline 11 & LSCC & IVa/ G3 & ++ & $\mathrm{TL}$ & $\begin{array}{c}\text { t for other } \\
\text { disease }\end{array}$ \\
\hline 12 & LSCC & "I/G2 & $++/+++$ & SCPL & $\begin{array}{l}t \text { for other } \\
\text { disease }\end{array}$ \\
\hline 13 & LSCC & IVa/G2- G3 & $++/+++$ & SCPL & $\begin{array}{l}\text { t for other } \\
\text { disease }\end{array}$ \\
\hline 14 & LSCC & II/ G2 & ++ & SGPL & Normal \\
\hline 15 & LSCC & III/ G3 & ++ & SCPL & Normal \\
\hline 16 & LSCC & $\mathrm{IVa} / \mathrm{G} 2-\mathrm{G} 3$ & +++ & SGPL & $t-\mathrm{M}_{+}$ \\
\hline 17 & LSCC & III/ G2 & ++ & SGPL & Normal \\
\hline 18 & LSCC & IVa/ G3 & +++ & SCPL & $t-\mathrm{M}_{+}$ \\
\hline 19 & LSCC & IVa/ G3 & +++ & $\mathrm{TL}$ & $t-\mathrm{M}_{+}$ \\
\hline 20 & LSCC & IVa/ G2 & ++ & SGPL & Normal \\
\hline 21 & LSCC & IVa/ G3 & +++ & SCPL & Normal \\
\hline 22 & LSCC & III/ G2- G3 & +++ & SGPL & $\begin{array}{l}t \text { for other } \\
\text { disease }\end{array}$ \\
\hline 23 & LSCC & IVa/ G2 & ++ & SCPL & $t$ \\
\hline 24 & LSCC & IVa/ G3 & +++ & SCPL & Normal \\
\hline 25 & LSCC & IVa/ G3 & +++ & $\mathrm{TL}$ & Normal \\
\hline 26 & LSCC & $\mathrm{IVa} / \mathrm{G} 2-\mathrm{G} 3$ & $++/+++$ & SCPL & $t-M_{+}$ \\
\hline 27 & LSCC & II/ G2 & ++ & SCPL & Normal \\
\hline 28 & LSCC & IVa/ G3 & +++ & SCPL & Normal \\
\hline 29 & LSCC & $\mathrm{IVa} / \mathrm{G} 2-\mathrm{G} 3$ & $++/+++$ & SCPL & Normal \\
\hline 30 & LSCC & $\mathrm{IVa} / \mathrm{G} 2-\mathrm{G} 3$ & +++ & $\mathrm{TL}$ & $t-\mathrm{M}_{+}$ \\
\hline
\end{tabular}

Abbreviations

LSCC: squamous cell carcinomas of the larynx; SCPL: supracricoid partial laryngectomy; SGPL: supraglottic partial laryngectomy; TL: total laryngectomy; † death; $M+$ metastasis

\section{Discussion}

Knowledge of the multistep laryngeal carcinogenesis mechanism is a prerequisite for the development of cancer prevention and treatment strategies. CAF1/p60 has been proposed as a new proliferation and prognostic marker in a series of different malignant tumours. The expression of the p60 subunit is particularly high in neoplasms with increased cellular proliferation: while CAF-1/p60 is down-regulated in resting cells, it is greatly overexpressed in neoplastic cells ${ }^{8}$. Moreover, the dissociation of CAF-1/p60 from hair- 

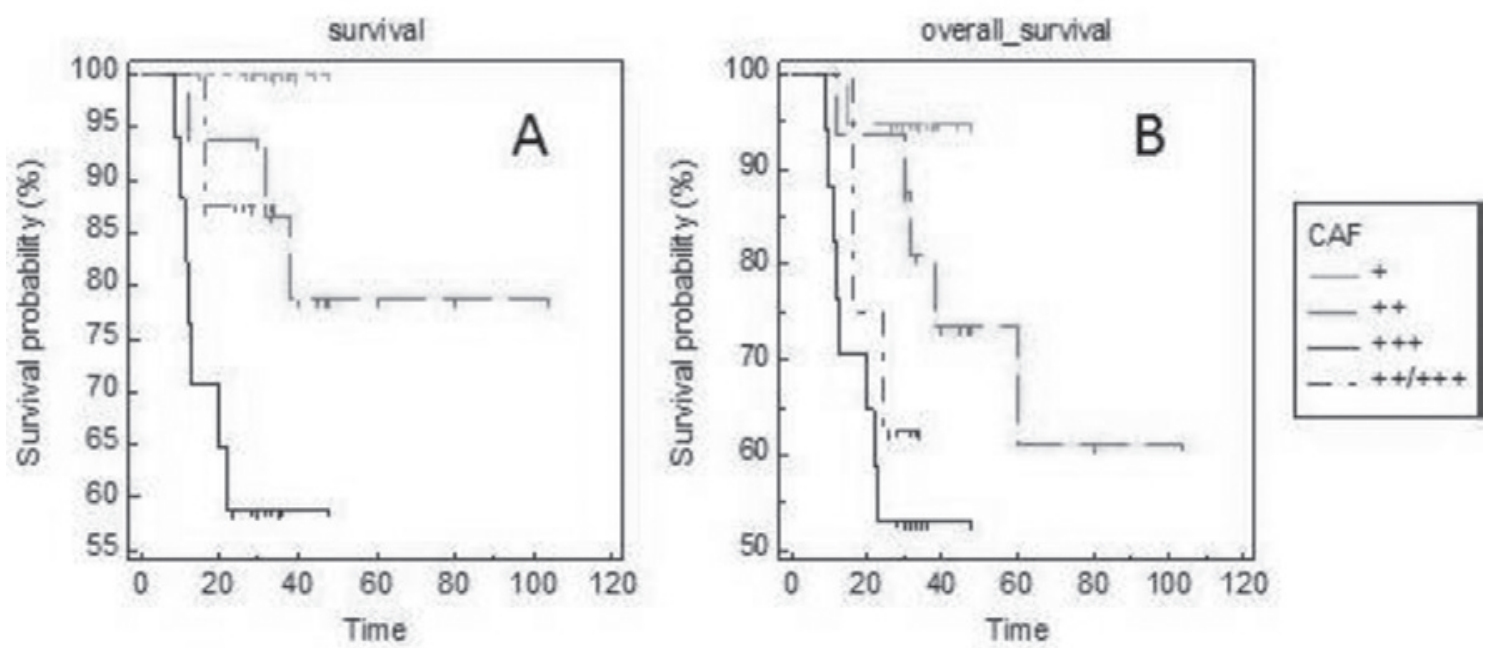

Fig. 2. Analysis of survival; A) disease-specific survival and B) overall survival.

pin replication causes the suspension of its activity in the nucleosomes assembly, with the arrest of hairpin replication, mitosis blocking during the cellular cycle and global alterations of chromatin in the $S$ phase ${ }^{25}$. In addition to being a reliable marker of cellular proliferation, $\mathrm{CAF}-1 /$ p60 also assumes a relevant value as reliable marker of tumour progression and as a predictor of biological behaviour ${ }^{26} 27$.

In fact, several recent reports have highlighted the strict relationship between $\mathrm{CAF}-1 / \mathrm{p} 60$ over-expression and adverse behaviour of different malignant tumours, including prostate, tongue, salivary glands carcinomas and cutaneous melanoma ${ }^{28-31}$. These studies have confirmed the hypothesis that CAF-1/p60 is heavily involved in tumoural and metastatic processes, constituting an independent prognostic biomarker of tumour evolution ${ }^{825}$ 32-34.

Our results indicate that the levels of expression of the CAF-1/p60 assume a significant $(\mathrm{p}<0.05)$ value for moderate/severe dysplastic lesions of the larynx compared with carcinomas in situ and when comparing both dysplasia and carcinomas in situ with infiltrating carcinomas of the larynx. Analysis of the surgical procedure allows us to confirm that excisional biopsy is a valid tool in treating the dysplasia, decisive in $100 \%$ of cases, while for carcinomas in situ excisional biopsy was the sole treatment performed in 19 patients, while a second surgical treatment was required in 9 patients. CAF-1/p60 expression was mild in all evaluated epithelial laryngeal dysplasia (100\%). With reference to the clinical behaviour of carcinoma in situ, we can assume that mild overexpression of CAF-1/p60 (mild +) is connected to a regular progress; in patients with a moderate to severe expression on the other hand there is an increase in repeat surgery and relapses.
It is possible to speculate that in cases of carcinoma in situ in which p60 is overexpressed, close follow-up is required to assess possible recurrence as promptly as possible and plan appropriate treatment. In infiltrating tumours of the larynx, p60 protein expression is moderate to high. In these patients, there is an increase in mortality and recurrence in accordance with the standard parameters of neoplasia (staging, grading); however, overexpression of CAF-1/p60 appears to be related to an independent risk of mortality associated with distant metastases, which are not common in tumours of the larynx. In fact, in 8 patients with moderate to high expression, the course of the disease was ominous, with distant metastases leading

\begin{tabular}{|c|c|c|c|c|c|c|}
\hline Covariates & b & SE & $\mathbf{p}$ & $\begin{array}{l}\text { HR } \\
\text { Explb) }\end{array}$ & $\begin{array}{l}95 \% \mathrm{C} \text { of } \\
\text { Exp(b) }\end{array}$ & D \\
\hline $\begin{array}{l}\text { Overexpressi } \\
\text { on }\end{array}$ & 0,948 & $\begin{array}{l}0,326 \\
4\end{array}$ & $\begin{array}{l}0,00366 \\
9\end{array}$ & 2,5815 & $\begin{array}{l}1,3659 \text { to } \\
4,8788\end{array}$ & $\begin{array}{l}P= \\
0,0009\end{array}$ \\
\hline Scaging & $\begin{array}{l}0,804 \\
5\end{array}$ & $\begin{array}{l}0,297 \\
9\end{array}$ & $\begin{array}{l}0,00691 \\
2\end{array}$ & 2,2357 & $\begin{array}{l}1,2507 \text { to } \\
3,9963\end{array}$ & $\begin{array}{l}P= \\
0,0013\end{array}$ \\
\hline Grading & $\begin{array}{l}0,595 \\
0\end{array}$ & $\begin{array}{l}0,249 \\
5\end{array}$ & 0,01711 & 1,8130 & $\begin{array}{l}1,1145 \text { to } \\
2,9495\end{array}$ & $\begin{array}{l}P= \\
0,0155\end{array}$ \\
\hline Treatment & $\begin{array}{l}1,072 \\
9\end{array}$ & $\begin{array}{l}0,330 \\
1\end{array}$ & $\begin{array}{l}0,00115 \\
3\end{array}$ & 2,9239 & $\begin{array}{l}1,5361 \text { to } \\
5,5655\end{array}$ & $\begin{array}{l}P= \\
0,0001\end{array}$ \\
\hline Proeress & $\begin{array}{l}2.864 \\
1\end{array}$ & $\begin{array}{l}0,881 \\
3\end{array}$ & $\begin{array}{l}0.00115 \\
5\end{array}$ & 17.5332 & $\begin{array}{l}3,1441 \text { to } \\
97,2750\end{array}$ & $\begin{array}{l}P< \\
0.0001\end{array}$ \\
\hline $\begin{array}{l}\text { Distant } \\
\text { metastasis }\end{array}$ & $\begin{array}{l}2,681 \\
6\end{array}$ & $\begin{array}{l}0,843 \\
0\end{array}$ & $\begin{array}{l}0,00146 \\
8\end{array}$ & 14,6078 & $\begin{array}{l}2,8228 \text { to } \\
75,5952\end{array}$ & $\begin{array}{l}P< \\
0,0001\end{array}$ \\
\hline
\end{tabular}

Fig. 3. Univariate analyses of overexpression, staging, grading, treatment strategy, progression and distant metastases. 


\begin{tabular}{llllll}
\hline Covariates & $\mathrm{b}$ & $\mathrm{SE}$ & $\mathrm{P}$ & $\mathrm{HR} \operatorname{Exp}(\mathrm{b})$ & $95 \% \mathrm{Cl}$ of Exp(b) \\
Overexpression & 1,1920 & 0,6607 & 0,07123 & 3,2936 & 0,9080 to 11,9462 \\
Staging & $-0,4976$ & 0,5706 & 0,3832 & 0,6080 & 0,1998 to 1,8499 \\
Grading & 2,3724 & 0,9982 & 0,01747 & 10,7233 & 1,5311 to 75,1051 \\
$\begin{array}{l}\text { Treatment } \\
\text { Progress }\end{array}$ & $-2,1509$ & 0,9578 & 0,02472 & 0,1164 & 0,0180 to 0,7533 \\
$\begin{array}{l}\text { Distant } \\
\text { metastasis }\end{array}$ & $-8,0267$ & 213,0050 & 0,9699 & 0,0003 & 0,0000 to $799 \mathrm{E}+174$ \\
\hline
\end{tabular}

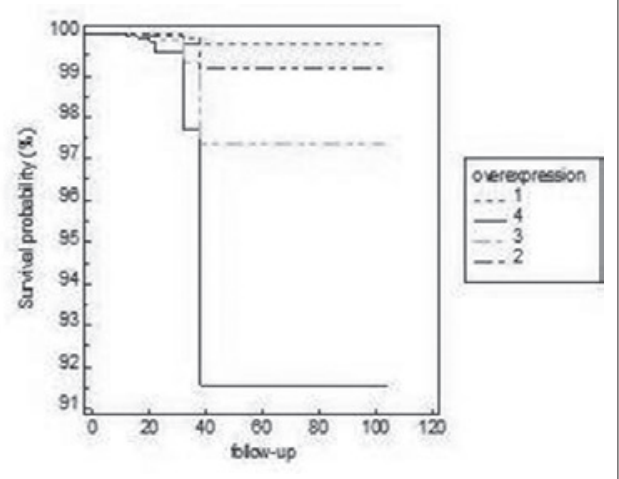

Fig. 4. Multivariate Cox regression analysis.

to death of both patients. This suggests that the overexpression of CAF can identify the subset of tumours with a more aggressive biological from among those having equivalent staging and grading.

In $36.6 \%$ of patients (11 cases) with carcinoma in situ, immunopositivity was moderate to high. In 9 patients, further surgery was required (5 cases of recurrence of carcinoma in situ, one case of laryngectomy and one patient death due to recurrence and progression of laryngeal cancer). The highest expression of protein characterised cases of metastatic SCC and the majority of carcinoma in situ (all except one) with a history of progressive disease (recurrence and/ or death due to disease). This clinical behaviour (need for further surgery, relapse and progression) highlights the need for a tighter follow-up timetable as a marker for such carcinoma in situ patients.

Analyses of survival indicate an increased risk of recurrence and mortality concurrent with the parameters assessed by univariate analyses that assume a predictive and statistical significance in each case (Fig. 3). Multivariate analysis of these variables showed that staging, grading, treatment strategy, progress, distant metastasis are all independent prognostic factors for patients with LSCCs, and overexpression of CAF-1/p60 protein is significantly associated with poor prognosis.

Multivariate analysis correlating risk of overexpression, considering the prognostic factors examined in the univariate analyse shows an increase in HR (2.58 versus 3.29$)$ compared to univariate analysis with a $\mathrm{p}<0.001$ (Fig. 4). Also worthy of note is the HR of the distant metastases, an expression of the aggressiveness of the disease.

\section{Conclusions}

Our results show that $\mathrm{CAF}-1 / \mathrm{p} 60$ in an independent prognostic factor that may better predict the biological behaviour of LSCC associated with traditional prognostic features, but this exciting hypothesis needs to be validated by a larger and more representative series of cases. If confirmed, we may adopt a more pronounced oncological follow-up protocol for the subset of patients with carcinoma in situ overexpressing CAF-1/p60 and adjuvant therapy programmes in infiltrating ones.

\section{References}

1 Torre LA, Bray F, Siegel RL, et al. Global cancer statistics, 2012. CA Cancer J Clin 2015;65:87.

2 Shan JP, Patel KJ. Head and neck surgery and oncology. $3^{\text {rd }}$ ed. Edinburgh: Mosby 2003.

3 Ferlay J, Soerjomataram I, Ervik M, et al. F. GLOBOCAN 2012 v1. 1, Cancer Incidence and Mortality Worldwide: IARC Cancer Base No. 11 [Internet]. Lyon: International Agency for Research on Cancer 2014.

4 Mesolella M, Iorio B, Misso G, et al. Role of perineural invasion as prognostic factor in laryngeal cancer. Oncology Letters 2016; 11;2595-8.

5 Vasca V, Vasca E, Freiman P, et al. Keratin 5 expression in squamocellular carcinoma of the head and Neck. Oncology Letter 2014;8:2501-4.

6 Ozanne SE, Constância M. Mechanisms of disease: the developmental origins of disease and the role of the epigenotype. Nat Clin Pract Endocrinol Metab 2007;3:539-46.

7 Ehrenhofer-Murray AE. Chromatin dynamics at DNA replication, transcription and repair. Eur J Biochem 2004;271:2335-49.

8 Linger JG, Tyler JK. Chromatin disassembly and reassembly during DNA repair. Mutat Res 2007;618:52-64.

9 Gaillard PH, Martini EM, Kaufman PD, et al. Chromatin assembly coupled to DNA repair: a new role for chromatin assembly factor I. Cell 1996;86:887-96.

10 Polo SE, Yheocharis SE, Klijaieko J, et al. CAF-1, a marker of clinical value to distinguish quiescent from proliferative cells. Cancer Res 2004;64:2371-81.

11 Tagami H, Ray-Gallet D, Almouzni G, et al. H3. 1 and H3. 3 complexes mediate nucleosome assembly pathways dependent or independent of DNA synthesis. Cell 2004;116:51-61.

12 Hoek M, Stillman B. CAF-1 is essential and couplet chromatin assembly to DNA replication in vivo. Proc Natl Acad SCI USA 2003;100:12183-8.

13 Shim KS, Bergelson JM, Furuse M, et al. Reduction of chromatin assembly factor 1 p60 and C21orf2 protein, encoded on chromosome 21, in Down syndrome brain. J Neural Transm Suppl 2003;67:117-28.

14 Taddei A, Roche D, Sibarita JB, et al. Duplication and manteinence of heterochromatin domains. J Cell Biol 1999;147:1153-66.

15 Verreault A, Kaufman PD, Kobayashi R, et al. Nucleosome as- 
sembly by a complex of CAF-1 and acetylated histones $\mathrm{H} 3 / \mathrm{H} 4$. Cell 1996;87:95.

${ }^{16}$ Liu WH, Roemer SC, Port AM, Churchill ME. CAF-1-induced oligomerization of histones $\mathrm{H} 3 / \mathrm{H} 4$ and mutually exclusive interactions with Asflguide $\mathrm{H} 3 / \mathrm{H} 4$ transitions among histone chaperones and DNA. Nucleic Acids Research 2012;40:11229-39.

17 Zhu Q, Wani G, Arab HH, et al. Chromatin restoration following nucleotide excision repair involves the incorporation of ubiquitinated H2A at damaged genomic sites. DNA Repair (Amst) 2009;8:262-73

18 Takami Y, Ono T, Fukagawa T, et al. Essential role of chromatin assembly factor-1-mediated rapid nucleosome assembly for DNA replication and cell division in vertebrate cells. Mol Biol Cell 2007;18:129-41.

19 Moggs J, Grandi P, Quivy JP, et al. A CAF-1-PCNA mediated Chromatin Assembly Pathway triggered by sensing DNA damage. Mol Cell Biol 2002;4:1206-18.

20 Kirik A, Pecinka A, Wendeler E, Reiss B. The chromatin assembly factor subunit 1 is involved in homologous recombination in plants. Plant Cell 2006;18:2431-42.

21 Shibahara K, Stillman B. Replication-dependent marking of DNA by PCNA facilitates CAF-1 coupled inheritance of chromatin. Cell 1999;96:575-85.

22 Krawitz DC, Kama T, Kaufman PD. Chromatin assembly factor I mutants defective for PCNA binding require Asf1/Hir proteins for silencing. Mol Cell Biol 2002;22:614-25.

23 Remacle M, Eckel HE, Antonelli A, et al. Endoscopic cordectomya proposal for a classification by the Working Committee, European Laryngological Society Eur Arch Otorhinolaryngol. Eur Arch Otorhinolaryngol 2000;257:227-31.

24 Mascolo M, Vecchione ML, Ilardi G, et al. Overexpression of Chromatin Assembly Factor-1/p60 helps to predict the prognosis of melanoma patients. BMC Cancer 2010;10:63.

25 Mello JA, Silljé HH, Roche DM, et al. Human Asfl and CAF-1 interact and synergize in a repair-coupled nucleosome assembly pathway. EMBO Rep 2002;3:329-34.

26 Polo SE, Theocharis SE, Grandin L, et al. Clinical significance and prognostic value of chromatin assembly factor-1 overexpression in human solid tumors. Histopathology 2010;57:716-24.

27 Tchénio T, Casella JF, Heidmann T. A truncated form of the human CAF-1 p150 subunit impairs the maintenance of transcriptional gene silencing in mammalian cells. Mol Cell Biol 2001;21:1953-61.

28 Staibano S, Mascolo M, Rocco A, et al. The proliferation marker Chromatin Assembly Factor-1 is of clinical value in predicting the biological behavior of salivary gland tumours. Oncol Rep 2011;25:13-22.

29 Staibano S, Mascolo M, Mancini FP, et al. Overexpression of chromatin assembly factor-1 (CAF-1) 060 is predictive of adverse behavior of prostatic cancer. Histopathology 2009;54:580-9.

30 Staibano S, Mignogna C, Lo Muzio L, et al. Chromatin assembly factor-1 (CAF-1)-mediated regulation of cell proliferation and DNA repair: a link with the biological behavior of squamous cell carcinoma of the tongue? Histopathology 2007;50:911-9.

31 Mascolo M, Ilardi G, Romano MF, et al. Overexpression of chromatin assembly factor-1 p60, poly(ADP-ribose) polymerase 1 and nestin predicts metastasizing behavior of oral cancer. Histopathology 2012;61:1089-1105.

32 Nabatiyan A, Krude T. Silencing of chromatin assembly factor 1 in human cells leads to cell death and loss of chromatin assembly during DNA synthesis. Mol Cell Biol 2004;24:2853-62.

33 Keller C, Krude T. J. Requirement of Cyclin/Cdk2 and protein phosphatase 1 activity for chromatin assembly factor 1-dependent chromatin assembly during DNA synthesis. Biol Chem 2000;275:35512-21.

34 Ahmad A, Takami Y, Nakayama T. WD repeats of the p48 subunit of chicken chromatin assembly factor-1 required for in vitro interaction with chicken histone deacetylase-2. J Biol Chem 1999;274:16646-53.

Address for correspondence: Massimo Mesolella, Department of Neurosciences, ENT Section, University of Naples "Federico II", Naples, 80138, Italy, A.O.U. Federico II, via S. Pansini 5, 80131, Naples. Tel. +39 817463497. Fax +39 817463592. E-mail: massimo.mesolella@tin.it 